Jurnal Ilmu-Ilmu Peternakan 25 (1): 66-71

ISSN: 0852-3581

E-ISSN: 9772443D76DD3

CFakultas Peternakan UB, http://jiip.ub.ac.id/

\title{
Screening sumber cemaran bakteri pada kegiatan pemerahan susu di peternakan sapi perah rakyat Kabupaten Semarang
}

\author{
Soni Prihutomo, Bhakti Etza Setiani dan Dian Wahyu Harjanti \\ Fakultas Peternakan dan Pertanian, Universitas Diponegoro \\ Kampus UNDIP Tembalang Semarang \\ dianharjanti@undip.ac.id
}

\begin{abstract}
The purpose of this experiment was to investigate the main source of bacteria contamination in milk at smallholder dairy farmers. The research was conducted at Margo Rukun dairy farm group in Semarang regency. Samples were milk and possible bacteria contamination sources during milking process such as: milk bucket swab, cow teat skin swab, farmer's hand swab, water used during milking and napkin for wiping the udder (cutted at $1 \times 1 \mathrm{~cm}$ square). Observed parameter was total number of bacteria using total plate count (TPC) method. The data were analyzed by t-test and linear regression analysis. The result showed that the total bacteria in milk were 320.143 $\mathrm{CFU} / \mathrm{ml}$. Total bacteria in the bucket $(320.143 \mathrm{CFU} / \mathrm{ml})$ was higher $(\mathrm{p}<0.05)$ than that in the water $(149.227 \mathrm{CFU} / \mathrm{ml})$. However, total bacteria in the water did not differ with the total bacteria in the teat skin $(109.833 \mathrm{CFU} / \mathrm{ml})$. Total bacteria in the teat skin were higher $(\mathrm{p}<0.05)$ than that in the napkin $(96.750 \mathrm{CFU} / \mathrm{ml})$ and in the farmer's hands (33.380 CFU/ml). Highest coeficient correlation ( $r=0.384)$ was found between total bacteria in milk and total bacteria in milk bucket, indicating that the milk bucket gave the highest contribution to bacteria contamination in milk.
\end{abstract}

Keywords: milk, bacteria, contamination, milking

\section{PENDAHULUAN}

Angka kebutuhan susu di Indonesia semakin tinggi seiring bertambahnya tahun, tetapi peningkatan tersebut belum diimbangi dengan kualitas dan kuantitas produksi susu yang setara dengan jumlah permintaan. Pasokan susu segar nasional hanya mencukupi kebutuhan sebanyak 30\% untuk seluruh Indonesia dan sisanya sebanyak $70 \%$ adalah impor (Purwono, 2013). Susu merupakan sumber gizi penting karena mengandung bahan esensial bagi tubuh seperti protein, karbohidrat, lemak dan mineral yang tidak hanya disukai oleh manusia tetapi juga oleh bakteri. Berdasarkan SNI
3141.1:2011 tentang susu segar, jumlah cemaran bakteri dalam susu maksimal $1 \times 10^{6} \mathrm{CFU} / \mathrm{ml}$. Jika jumlah bakteri dalam susu melebihi angka tersebut, maka susu akan ditolak oleh industri pengolahan susu.

Provinsi Jawa Tengah memiliki potensi yang besar untuk pengembangan ternak perah dan industri persusuan. Beberapa sentra peternakan sapi perah di Jawa Tengah antara lain Kabupaten Boyolali, Kabupaten Semarang, Kabupaten Banyumas dan Kabupaten Klaten. Berdasarkan hasil evaluasi yang telah dilakukan di Kabupaten Banyumas, jumlah bakteri dalam susu di tingkat peternak mencapai $2,6 \times 10^{6}$ 
CFU/ml (Rifai dkk, 2014). Data evaluasi cemaran bakteri dalam susu di Kabupaten Semarang belum ada. Padahal, Kabupaten Semarang memiliki potensi besar dalam industri persusuan jika dilihat dari semakin banyaknya IPS yang menanamkan investasi disekitar wilayah Kabupaten Semarang, diantaranya yaitu Cimory, Cita Nasional, Frisian Flag dan Indolakto.

Tingginya jumlah cemaran bakteri dalam susu tidak terlepas dari manajemen sanitasi pada saat pemerahan. Higiene peralatan dan pemerah juga memiliki pengaruh terhadap besarnya jumlah bakteri pada susu saat sebelum proses pengiriman untuk diproses lebih lanjut (Firman, 2010). Bertitik tolak dari hal tersebut maka penelitian ini dilakukan untuk mengetahui sumber pencemaran bakteri terbesar dalam proses pemerahan yang dapat menurunkan kualitas susu.

\section{MATERI DAN METODE}

Penelitian dilaksanakan dengan mengambil sampel dari 30 peternakan sapi perah rakyat anggota Kelompok Tani Ternak (KTT) Margo Rukun Kabupaten Semarang. Materi penelitian ini adalah susu sapi, hasil swab ember susu, swab puting, swab tangan pemerah, air basuh ambing dan potongan kain lap yang digunakan untuk mengeringkan ambing. Alat yang digunakan dalam penelitian ini adalah aquades steril, petrifilm $3 \mathrm{M}$ dan inkubator.

Cara yang dilakukan dalam proses pengambilan sampel mengikuti teknik dari (Boel, 2004) yaitu:

1) Suci hama tangan dengan air mengalir dan alkohol $70 \%$.

2) Menyiapkan botol sampel berbahan kaca dengan penutup steril. Botol sampel yang berisi sampel padat (swabber dan lap) diisi aquades steril sebanyak $60 \mathrm{ml}$.
3) Mengusapkan swabber sebanyak tiga kali dan memutar penuh ke masing-masing jenis sampel.

4) Memasukkan swabber dengan segera kedalam botol sampel.

5) Pengambilan sampel air dilakukan menggunakan pipet steril sebanyak $60 \mathrm{ml}$.

6) Pengambilan sampel lap adalah dengan memotong bagian tengah lap berukuran $1 \times 1 \mathrm{~cm}$. Pengambilan lap pada bagian tengah yang paling sering bersentuhan dengan ambing.

7) Botol sampel disimpan di dalam cooler box dengan segera pada suhu $2-4^{\circ} \mathrm{C}$.

\section{Total plate count (TPC)}

Uji TPC dilakukan dengan inokulasi sampel kedalam Petrifilm 3M. Sampel diinkubasi pada suhu $37^{\circ} \mathrm{C}$ selama $24 \mathrm{jam}$. Total bakteri ditentukan dengan menggunakan metode TPC (Total Plate Count) (Gungor and Gokuglu, 2010). Jumlah bakteri (CFU/ml) dihitung berdasarkan rumus:

$\underline{\text { Jumlah titik (faktor pengenceran) }}$

Jumlah ml sampel diinnokulasi

\section{Analisis data}

Data diuji dengan menggunakan uji t dan regresi linear dengan persamaan $\mathrm{y}=\mathrm{ax}+\mathrm{b}$

$\mathrm{y}=$ variabel terikat (jumlah bakteri dalam susu)

$\mathrm{x}=$ variabel bebas (jumlah bakteri ember, air, puting, lap, tangan)

$\mathrm{a}=$ intersep/konstanta/perpotongan antara garis dengan sumbu y

\section{HASIL DAN PEMBAHASAN}

\section{Jumlah bakteri dalam susu}

Hasil yang didapat dari uji TPC menunjukkan bahwa jumlah bakteri dalam susu di tingkat peternak KTT 
Margo Rukun adalah 311.759 CFU/ml. Jumlah bakteri tersebut berada dibawah nilai maksimum cemaran bakteri yang disyaratkan oleh SNI, sehingga dari hasil penelitian ini dapat diketahui bahwa susu yang dihasilkan oleh peternak sapi perah di KTT Margo Rukun memiliki kualitas yang baik. Hal tersebut dikarenakan pada saat proses kegiatan pemerahan peternak menerapkan sistem pemerahan dan sanitasi yang baik, sesuai dengan pendapat Santoso, dkk, 2010) yang menyatakan bahwa kebersihan kandang dan tubuh sapi berkaitan erat dengan kualitas susu. Usaha membersihkan kandang dan bagian-bagian tubuh sapi yang dapat mengotori hasil pemerahan bisa dilakukan menggunakan langkah- langkah sebagai berikut:

1) Mencuci lantai kandang dengan menyemprotkan air bertekanan tinggi.

2) Mencuci lipatan paha, ambing dan puting pada sapi sembari dipijat secara perlahan menggunakan air hangat.

3) Mengeringkan puting dengan kain bersih.

4) Membuang susu pada pancaran pertama.

\section{Jumlah cemaran bakteri pada kegiatan pemerahan}

Jumlah cemaran bakteri pada kegiatan pemerahan susu sapi dapat dilihat pada Tabel 1.

Tabel 1. Hasil uji total bakteri kegiatan pemerahan

\begin{tabular}{cccccc}
\hline & Ember & Air & Putting & Lap & Tangan \\
\hline $\begin{array}{c}\text { Total bakteri } \\
(\text { CFU/ml })\end{array}$ & $320.143^{\mathrm{a}}$ & $149.227^{\mathrm{b}}$ & $109.833^{\mathrm{b}}$ & $96.750^{\mathrm{c}}$ & $33.380^{\mathrm{c}}$ \\
\hline
\end{tabular}

Keterangan: ${ }^{a b c}$ Superskrip yang berbeda menunjukkan adanya beda nyata $(\mathrm{p}<0,05)$.

Hasil yang didapat dari uji total bakteri menunjukkan bahwa ember dan air, serta puting dan lap terdapat perbedaan nyata $(\mathrm{p}<0,05)$. Sedangkan air dan puting serta lap dan tangan menunjukkan tidak adanya perbedaan nyata $(\mathrm{p}>0,05)$. Hasil rata-rata total bakteri tangan menunjukkan angka yang paling kecil. Hal tersebut dikarenakan peternak selalu menjaga higienitas tangan pada saat persiapan sebelum pemerahan dan juga saat pemerahan, peternak selalu mencuci tangan pada masing-masing sapi yang diperah. Selain itu peternak menggunakan air mengalir sebagai sanitasi tubuh. Hal tersebut sesuai dengan pendapat Cahyono dkk (2013) bahwa kontaminasi pemerah seringkali berasal dari tangan pemerah itu sendiri karena kebersihan tangan pemerah sering tidak diperhatikan. Upaya yang dapat dis- arankan yaitu pemerah mencuci tangan sebelum melakukan pemerahan.

Rata-rata nilai total bakteri yang didapat dari ember penampung susu memiliki angka total bakteri yang paling tinggi. Tingginya angka ini disebabkan oleh penggunaan ember berbahan plastik polipropilena yang tidak memiliki standar sebagai wadah tempat susu yang telah ditetapkan oleh SNI (1992) yaitu: (1) terbuat dari bahan aluminium dengan permukaan yang berhubungan langsung dengan susu harus dibuat rata dan licin, (2) hasil pengelasan pada penyambungan bagian luar dinding harus kuat dan baik, (3) tutup bejana berbentuk sedemikian rupa, sehingga kuat, mudah dibersihkan dan tidak berbentuk sudut yang memungkinkan masuknya penyebab kontaminasi, (4) tahan terhadap tingkat keasaman yang terdapat pada susu segar 
yaitu $\quad 4,5-7^{\circ} \mathrm{SH}$. Sheehan (2013) menambahkan bahwa kualitas susu dapat dipengaruhi oleh beberapa karakteristik yaitu bakteri (pathogen maupun non-pathogen), kimia, komposisi, fisis, enzimatik dan pemalsuan.

Minimnya penggunaan ember berbahan stainless steel dikarenakan oleh kurangnya pengetahuan peternak tentang pentingnya penekanan angka bakteri pada peralatan pemerahan khususnya pada ember wadah susu. Selain itu juga dikarenakan harganya yang dirasa relatif mahal bagi peternak dan minimnya harga jual susu yang diterima oleh peternak untuk mengembangkan sumber dayanya. Hal ini merupakan dilema global di industri persusuan Indonesia. Selain dapat menyebabkan perkembangan bakteri lebih cepat, ember berbahan plastik polipropilena dapat menyebarkan residu yang disebabkan oleh sifat fisik dan kimiawi dari bahan tersebut oleh produk pangan terutama susu. Di Kecamatan Getasan, peternak yang menggunakan ember berbahan plastik jauh lebih banyak dibandingkan peternak yang menggunakan ember berbahan stainless steel. Dari 30 peternak yang dijadikan sebagai responden, hanya $20 \%$ diantaranya yang menggunakan ember berbahan stainless steel, sisanya menggunakan ember berbahan plastik. Derajat higienitas sanitasi pemerahan meliputi kebersihan kandang, kebersihan peralatan, kebersihan karyawan dan kebersihan sapi. Diantara hal tersebut, hal yang paling mempengaruhi higienitas pemerahan adalah kebersihan peralatan Ngadiani dan Herlin (2006).
Pada hasil uji total bakteri pada kegiatan pemerahan didapatkan hasil cemaran pada air basuh memiliki jumlah yang tinggi. Tingginya angka bakteri pada air basuh tidak disebabkan oleh pencemaran pada sumber air yang digunakan oleh peternak KTT Margo Rukun karena sebagian besar mengambil dari sumur resapan. Menurut Wiryono (2013), pada pencemaran air, ada polusi yang tak bersumber pada titik tertentu (non point-source polution) yaitu polusi yang berasal dari limbah rumah tangga, kotoran manusia atau hewan dan limbah industri.

Hasil total bakteri pada puting tidak memiliki perbedaan nyata terhadap jumlah bakteri pada air basuh ambing tetapi masih terbilang tinggi. Hal tersebut dikarenakan seluruh peternak di KTT Margo Rukun mengaplikasikan sistem kandang terikat dimana sapi tidak dapat bergerak kemanapun dan seluruh aktivitas sapi dilakukan di satu tempat termasuk membuang kotoran. Pada hasil total bakteri lap, didapatkan hasil yang relatif kecil dan mengalami perbedaan nyata dari jumlah bakteri pada puting. Hal tersebut dikarenakan pada kegiatan sanitasi, lap jarang diganti untuk setiap ekor sapi bahkan setiap harinya. Lap hanya disimpan pada penggantung kain di tempat terbuka dalam kandang dan hanya dibersihkan menggunakan air, padahal air tersebut memiliki angka bakteri yang tinggi. Rendahnya angka bakteri pada lap dikarenakan lap digantung pada tempat yang terkena sinar matahari, sehingga dapat membunuh sebagian bakteri yang terdapat pada lap. 
Jumlah bakteri pada tangan tidak memiliki perbedaan nyata terhadap jumlah bakteri pada kain lap. Hal tersebut dikarenakan pada setiap kali peternak akan melakukan pemerahan, peternak selalu mencuci tangan dan beberapa peternak mencuci tangan pada setiap ekor sapi yang diperah.
Hubungan antara jumlah bakteri dalam susu dengan kegiatan pemerahan (air basuh, tangan pemerah, kain lap, ember penampung susu dan puting sapi).

Hubungan antara total bakteri susu terhadap kegiatan pemerahan ditampilkan pada Tabel 2 .

Tabel 2. Hubungan total bakteri susu terhadap kegiatan pemerahan

\begin{tabular}{clccccc}
\hline & & Ember & Air & Puting & Lap & Tangan \\
\hline Jumlah bakteri susu & $\mathrm{r}$ & 0,384 & 0,30 & 0,22 & 0,095 & 0,064 \\
& $\mathrm{R}^{2}$ & $14,8 \%$ & $9 \%$ & $0,9 \%$ & $0,4 \%$ & $0 \%$ \\
\hline
\end{tabular}

Pada hasil pengujian regresi menunjukkan skala hasil $r$ terbesar adalah pada ember penampung susu sebesar 0,384. Hal ini menunjukkan bahwa ember penampung susu mempunyai kontribusi terbesar dalam tingginya cemaran bakteri dalam susu. Disamping higienitas peralatan pemerahan, prosedur pemerahan yang baik dan benar (good milking practice), yang mencakup sanitasi kandang dan ternak merupakan upaya untuk meminimalisir cemaran bakteri sehingga diharapkan dapat meningkatkan kualitas susu (Achroni, 2013). Penerapan sistem keamanan pangan pada setiap proses produksi melalui Good Farming Practice (GFP), Good Handling Practice (GHP), dan Good Manufacturing Practice (GMP) perlu dilakukan untuk mengendalikan residu dan cemaran mikroba dalam proses pemerahan susu (Gustiani, 2009).

\section{KESIMPULAN}

Penelitian ini menyimpulkan bahwa dalam kegiatan pemerahan, kontributor cemaran bakteri yang terbesar adalah ember penampung susu. Tingginya total bakteri disebabkan karena peternak tidak melakukan desinfeksi pada ember penampung susu dan menggunakan ember berbahan plastik sehingga lebih sulit dibersihkan.

\section{DAFTAR PUSTAKA}

Achroni, D. 2013. Kiat sukses usaha sapi perah skala kecil. Trans Idea Publishing. Yogyakarta.

Badan Standarisasi Nasional Indonesia. 1992. Wadah susu segar dari aluminium. Jakarta.

Boel, T. 2004. Cara pengambilan dan pengiriman bahan pemeriksaan. Pustaka Fakultas Kedokteran Gigi, Universitas Sumatera Utara. Medan.

Cahyono, D., M. Ch. Padaga dan M. E. Sawitri. 2013. Kajian kualitas mikrobiologis (total plate count (TPC), Enterobactericeae dan Staphylococcus aureus) susu sapi segar di Kecamatan Krucil Kabupaten Probolinggo. Jurnal Ilmu dan Teknologi Hasil Ternak 8 (1):1-8.

Firman, A. 2010. Agribisnis sapi perah: Bisnis sapi perah dari hulu sampai hilir. Widya Padjadjaran. Bandung.

Gungor, E. dan N. Gokoglu. 2010. Determination of microbial contamination sources at Frankfurter sausage processing line. Turkey Journal Veterinary Animal Science 34(1): 53-59.

Gustiani, E. 2009. Pengendalian cemaran mikroba pada bahan pangan asal ternak (daging dan susu) 
mulai dari peternakan sampai dihidangkan. Jurnal Litbang Peternakan, 28 (3): 96-100.

Ngadiani dan Herlin S. 2006. Hubungan antara derajat higienis sanitasi kandang terhadap jumlah bakteri MPN Coliform pada susu sapi perah. Journal of Science Volume 1(2): 22-30.

Purwono. 2013. Pengendalian cemaran mikroba pada bahan pangan asal ternak (daging dan susu) mulai dari peternakan sampai dihidangkan. Balai Pengkajian Teknologi Pertanian Jawa Barat. Lembang.

Rifai, J., Harjanti D.W. dan Nurwantoro. 2015. Jumlah cemaran bak- teri pada susu sapi segar di tingkat peternak, loper, dan KUD di Kabupaten Banyumas. Journal of Animal and Agriculture [in press].

Santoso, I., S. Wijana dan W. H. Pratiwi. 2010. Penerapan logika fuzzy pada penilaian mutu susu segar. Jurnal Teknologi Pertanian 11 (1) : 47-53.

Sheehan, J. J. 2013. Milk quality and cheese diversification. Irish Journal of Agricultural and Food Research 52: $243-253$.

Wiryono. 2013. Pengantar ilmu lingkungan. Yayasan Obor Indonesia. Jakarta. 